\title{
BV-constructies in de zorgsector: van schijn naar werkelijkheid
}

\author{
Mr.dr. A. G.H. Kla as sen*
}

\begin{abstract}
$Z$ ijn $B V$-constructies in de zorgsector in strijd met het verbod op winstuitkering en het bezoldigingsmaximum? Deze vraag kan ontkennend worden beantwoord. Over of het in strijd is met de geest van de relevante wetten kan verschillend worden gedacht. De auteur doet voorstellen tot aanpassing van het wetsvoorstel Wet toetreding zorgaanbieders en de Governancecode Zorg.
\end{abstract}

IGJ, Inspectie Gezondheidszorg en Jeugd

NZa, Nederlandse Zorgautoriteit

pgb, persoonsgebonden budget

VWS, Volksgezondheid, Welzijn en Sport

Wkkgz, Wet kwaliteit, klachten en geschillen zorg

Wlz, Wet langdurige zorg

Wmg, Wet marktordening gezondheidszorg

Wmo, Wet maatschappelijke ondersteuning

WNT, Wet normering topinkomens

Wtza, Wet toetreding zorgaanbieders

WTZi, Wet toelating zorginstellingen

ZBC, zelfstandig behandelcentrum

Zvw, Zorgverzekeringswet

\section{Inleiding}

Op 1 november 2017 kopte Het Financieele Dagblad 'Beloningsplafond en verbod op winst simpel te omzeilen' en 'Financieel toezicht blijkt in de praktijk wassen neus.' ${ }^{1}$ Wat is er aan de hand? Uit deze krantenartikelen blijkt dat met name kleine zorgaanbieders een BV oprichten om het bezoldigingsmaximum in de Wet normering topinkomens (WNT) en het verbod op winstuitkering in de Wet toelating zorginstellingen (WTZi) te omzeilen. ${ }^{2}$

Het fenomeen is overigens niet onbekend, zo blijkt uit een artikel uit 2010 in het Nederlands Juristenblad. ${ }^{3}$ In 2016 was

\footnotetext{
* Mr. dr. A.G.H. Klaassen is universitair docent ondernemingsrecht aan de Erasmus Universiteit Rotterdam; zij is lid van een raad van toezicht van een stichting in de eerstelijnsgezondheidszorg.

1. Zie S. Eikelenboom \& M. ten Katen, Beloningsplafond en verbod op winst simpel te omzeilen, Het Financieele Dagblad 1 november 2017 (hierna: 2017a), en van dezelfde auteurs: Financieel toezicht blijkt in de praktijk wassen neus, Het Financieele Dagblad 1 november 2017 (hierna: 2017b).

2. Zie voor de gebruikte afkortingen en hun betekenis ook het kader hierboven.

3. K. Meersma, Winstuitkering door ziekenhuizen, NJB 2010/1152.
}

er ook al maatschappelijke ophef. In juni van dat jaar verscheen een bericht op de website van Omroep Gelderland dat miljoenen euro's zorggeld verdwijnen in de zakken van directeuren. ${ }^{4}$ In september 2016 is in een column in Medisch Contact de truc van omzeiling ook al aan de orde gesteld. ${ }^{5}$

Het voorafgaande roept een aantal vragen op: (1) hoe zit deze $\mathrm{BV}$-constructie in de zorgsector in elkaar, waarmee het verbod op winstuitkering in de WTZi en het beloningsplafond in de WNT worden omzeild; (2) in hoeverre is deze constructie in strijd met de WTZi en de WNT; (3) is er voldoende (toe)zicht op deze BV-constructie; en (4) hoe kan deze BVconstructie eventueel worden tegengegaan, indien deze als onwenselijk wordt beschouwd?

De opzet van deze bijdrage is als volgt. In paragraaf 2 leg ik uit hoe de BV-constructie werkt. Paragraaf 3 gaat in op (het verbod op winstuitkering in) de WTZi en paragraaf 4 op (het bezoldigingsmaximum in) de WNT. De rol van het intern en extern toezicht is onderwerp van paragraaf 5 . In paragraaf 6 worden twee voorstellen tot wijziging uitgewerkt. Paragraaf 7 bevat de conclusie en de aanbevelingen.

\section{BV-constructie: een nadere verdieping}

\subsection{WTZi en WNT in het kort}

Zorgaanbieders die zorg willen aanbieden die onder de Zorgverzekeringswet $(\mathrm{Zvw})$ of de Wet langdurige zorg (Wlz) valt, hebben een zogeheten $W T Z i$-toelating nodig. Deze toelating is geregeld in de WTZi. ${ }^{6}$ Met de WTZi-toelating kan de zorgaanbieder de geleverde zorg declareren bij de zorgverzekeraar of het zorgkantoor. ${ }^{7}$ Van oudsher zijn het stichtingen die zorg verlenen. Stichtingen mogen op grond van Boek 2 van het Burgerlijk Wetboek (BW) geen winst uitkeren. ${ }^{8}$ De WTZi maakt overigens geen keuze voor een bepaalde rechtsvorm. Zorginstellingen kunnen bijvoorbeeld ook een BV zijn. Een

4. Zie www.omroepgelderland.nl/nieuws/2112374/Miljoenen-aan-zorggeld -verdwijnen-in-zakken-directeuren.

5. M. Levi, Twee maten, Medisch Contact 22 september 2016.

6. De ene zorgwet spreekt over zorginstellingen (bijv. de WTZi), een andere wet over zorgaanbieders (bijv. de Wkkgz). Ik zal beide termen door elkaar gebruiken.

7. Zorgkantoren zijn zelfstandig werkende kantoren die nauw gelieerd zijn aan de grootste zorgverzekeraar ter plekke. Het zorgkantoor regelt de zorg of het pgb voor mensen met een indicatie voor zorg vanuit de Wlz.

8. Art. 2:285 lid 3 BW. 


\section{Maandblad}

\section{Figuur 1 De BV-contstructie}

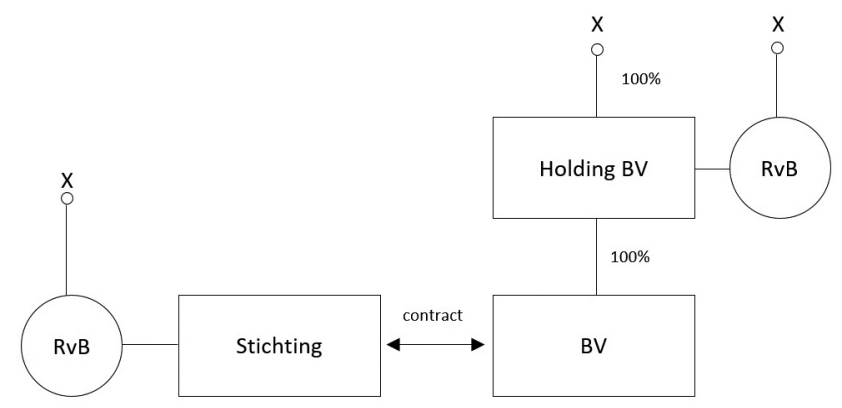

BV mag op grond van Boek 2 BW wel winst uitkeren. ${ }^{9}$ In de WTZ $\mathrm{i}$ is bepaald welke zorginstellingen winst mogen uitkeren en welke niet. ${ }^{10}$ Voor bestuurders van WTZi-instellingen geldt op grond van de WNT een bezoldigingsmaximum. Voor 2018 is het bezoldigingsmaximum EUR 187.000. ${ }^{11}$

\subsection{Praktijk}

De BV-constructie ${ }^{12}$ houdt in dat de stichting (de hoofdaannemer) de zorg uitbesteedt aan een BV, de onderaannemer (zie figuur 1). ${ }^{13}$ De stichting contracteert met de zorgverzekeraar. Deze (onderaannemings-)BV heeft geen WTZi-toelating nodig (zie par. 3) en voor deze BV geldt dus niet het verbod op winstuitkering of het bezoldigingsmaximum voor de bestuurder van deze BV (zie par. 4). De bestuurder van de stichting is ook de aandeelhouder en bestuurder van de BV, al dan niet via een persoonlijke holding. ${ }^{14}$

De BV-constructie wordt vooral gebruikt door zorginstellingen met een omzet van minder dan EUR 12 miljoen. ${ }^{15}$ Volgens Het Financieele Dagblad komt de constructie voor bij privéklinieken $^{16}$ en in de geestelijke gezondheidszorg, de gehandicaptenzorg en de thuiszorg. ${ }^{17} \mathrm{Ik}$ spits mijn bijdrage toe op deze sectoren. De zorg in deze sectoren wordt (hoofdzake-

9. Art. 2:216 BW

10. Art. 5 lid 2 WTZi. Zie verder par. 3.1

11. Stcrt. 2017, 51696. Zie verder par. 4.

12. In de zorg zijn meer BV-constructies bekend, zoals een stichting met allerlei BV's eronder. Deze constructies zijn geen onderdeel van deze bijdrage.

13. Onder uitbesteding en onderaanneming wordt verstaan het niet feitelijk zelf verlenen van gecontracteerde zorg door de toegelaten zorgaanbieder, maar het voor de zorgverlening gebruik maken van een andere (rechts)persoon. Zie S. Rijpma \& J. van den Nouwland, Investeren in de zorg, (on)mogelijkheden, TOP 2013, p. 79.

14. Eikelenboom \& Ten Katen 2017a; 2017b.

15. Zie ook Kamerstukken II 2017/18, 28828, 104, p. 9, waarin wordt verwezen naar het onderzoek van H. Verbon en J. Suijs (UvT), waarop het bericht van Omroep Gelderland is gebaseerd (zie noot 4).

16. Een privékliniek levert alleen onverzekerde zorg, in tegenstelling tot een ZBC, dat verzekerde zorg levert. Zie voor deze definities NZa, Monitor Zelfstandige behandelcentra, april 2012. In dit artikel zal ik beide behandelen.

17. Eikelenboom \& Ten Katen 2017a; 2017b. De zorgwetten gebruiken deze benamingen voor deelsectoren niet. Per wet zal ik de wettekst proberen te 'vertalen' naar de genoemde deelsectoren. Er zijn ook andere sectoren, zie hiervoor www.igl.nl/zorgsectoren. lijk ${ }^{18}$ ) gefinancierd vanuit de Zvw, de Wlz en de Wet maatschappelijke ondersteuning (Wmo).

De vraag is of de onderaannemingsconstructie in de genoemde sectoren in strijd is met de WTZi en de WNT dan wel de geest van de WTZi en de WNT (par. 3 en 4).

\section{WTZi}

De WTZi geldt sinds 2006, het jaar van de invoering van het nieuwe zorgstelsel. ${ }^{19} \mathrm{Er}$ zijn momenteel drie relevante wetsvoorstellen aanhangig. Bij de Eerste Kamer ligt sinds $2014^{20}$ het wetsvoorstel Wet vergroten investeringsmogelijkheden in medisch specialistische zorg. ${ }^{21}$ Dit wetsvoorstel maakt gereguleerde winstuitkering mogelijk voor aanbieders van de medisch specialistische zorg. In 2017 zijn aan de Tweede Kamer het wetsvoorstel Wet toetreding zorgaanbieders (Wtza) en het wetsvoorstel Aanpassingswet Wet toetreding zorgaanbieders aangeboden. ${ }^{22}$ Deze wetsvoorstellen herzien de procedure van toelating van zorginstellingen.

\subsection{Huidig recht}

Op grond van artikel 5 lid 1 WTZi heeft een instelling toelating nodig indien deze instelling zorg verleent waarop aanspraak bestaat op grond van de Zvw of de Wlz. Dit betekent dat in beginsel zelfstandige behandelcentra (ZBC's), instellingen voor geestelijke gezondheidszorg, gehandicaptenzorg en thuiszorg een WTZi-toelating nodig hebben. ${ }^{23}$ Zorgaanbieders die zorg leveren die geheel wordt betaald vanuit een per-

18. De zorg kan ook worden gefinancierd vanuit de Jeugdwet; deze wet laat ik buiten beschouwing.

19. Het nieuwe zorgstelsel bestaat uit de invoering van de $Z_{v w}$, de WTZi en de Wet marktordening gezondheidszorg (Wmg).

20. De Eerste Kamer zou in december 2014 over het wetsvoorstel stemmen, maar het is aangehouden.

21. Kamerstukken I 2013/14, 33168, A (Wijziging van de Wet toelating zorginstellingen en enkele andere wetten teneinde investeringsmogelijkheden in medisch-specialistische zorg te bevorderen). Bij indiening bij de Tweede Kamer luidde het wetsvoorstel 'Wijziging van de Wet toelating zorginstellingen en enkele andere wetten om het mogelijk te maken dat aanbieders van medisch-specialistische zorg, mits zij aan een antal voorwaarden voldoen, winst uitkeren (voorwaarden voor winstuitkering aanbieders medisch-specialistische zorg)'. Zie hierover E. Plomp, Kanttekeningen bij het wetsvoorstel vergroten investeringsmogelijkheden in medisch-specialistische zorg, Ondernemingsrecht 2014/146.

22. Kamerstukken II 2016/17, 34767, 2 en Kamerstukken II 2016/17, 34768, 2.

23. Zie art. 1.2 Uitvoeringsbesluit WTZi. 


\section{Maandblad}

Ondernemingsrecht

soonsgebonden budget (pgb) of zorg leveren die valt onder de Wmo hebben geen WTZi-toelating nodig. ${ }^{24}$ Privéklinieken hebben ook geen WTZi-toelating nodig. ${ }^{25}$

Voor de onderaannemings-BV geldt dat de hoofdaannemer contracteert met de zorgverzekeraar; de onderaannemer heeft daarom voor de zorgverlening geen WTZi-toelating nodig. $^{26}$

In 2006 liet toenmalig minister van Volksgezondheid, Welzijn en Sport (VWS), Hoogervorst, al weten dat het toegestaan is dat zorginstellingen werkzaamheden uitbesteden. Het uitbesteden is vooral belangrijk in geval van schoonmaak, catering en beveiliging, maar ook de zorgverlening kan worden uitbesteed aan een BV. ${ }^{27}$ Ook toenmalig minister Schippers van VWS laat in november 2016 weten dat WTZi-toegelaten instellingen in beginsel vrij zijn om derden te betrekken bij het verlenen van zorg, bijvoorbeeld door een deel van de activiteiten uit te besteden aan een andere partij. Een instelling kan volgens haar daartoe besluiten indien uitbesteden leidt tot betere of goedkopere zorg. ${ }^{28}$ Dit betekent dat onderaanneming an sich niet ongewenst hoeft te zijn.

Een onderaannemer zonder WTZi-toelating is niet gebonden aan de bepalingen in de WTZi, waaronder het verbod op winstuitkering. Dit lijkt ongewenst, maar winstuitkering is naar huidig recht, op grond van artikel 5 lid $2 \mathrm{WTZi}$, niet voor alle WTZi-instellingen verboden. De gedachte achter artikel 5 lid 2 WTZi bij de invoering van het nieuwe zorgstelsel was, in lijn met het stelsel daarvoor, dat collectieve middelen niet als winstuitkering aan aandeelhouders ten goede mochten komen in plaats van aan de zorg. ${ }^{29}$ Als vuistregel geldt naar huidig recht dat winstuitkering is verboden voor intramurale zorg ${ }^{30}$ en is toegestaan voor extramurale zorg. ${ }^{31,32}$

Thuiszorginstellingen en instellingen voor extramurale geestelijke gezondheidszorg en extramurale gehandicaptenzorg

24. Zie www.wtzi.nl/veelgestelde-vragen\#wel-of-geen-toelating-nodig.

25. Privéklinieken staan wel onder toezicht van de IGJ.

26. L. de Jongh \& L. Houwen, Winstuitkering en uitbesteding van medischspecialistische zorg, in: B. Berden e.a. (red.), Financiering van zorginstellingen, Deventer: Vakmedianet 2015, p. 207. Zie ook www.wtzi.nl/ veelgestelde-vragen\#wel-of-geen-toelating-nodig.

27. Kamerstukken II 2005/06, 29689, 90, p. 3.

28. Aanhangsel Handelingen II $2016 / 17,449$.

29. Kamerstukken II 2000/01, 27659, 3, p. 20. Het verbod op winstuitkering kan ook worden omzeild door het verschaffen van een (achtergestelde) lening met een variabel rentepercentage, zie Meersma 2010.

30. Intramurale zorg betreft de zorg die cliënten ontvangen gedurende een onafgebroken verblijf in een instelling. Het gaat om zorg in een verpleeghuis of verzorgingshuis, een instelling voor gehandicapten of instelling voor cliënten met langdurige psychische problemen. Intramurale zorg valt voornamelijk onder de Wlz.

31. Extramurale zorg betreft de zorg aan cliënten die niet in een instelling verblijven. Het is zorg die de cliënt op afspraak bij de zorgaanbieder krijgt, of die de zorgaanbieder bij de cliënt aan huis levert. Extramurale zorg valt voornamelijk onder de Wmo en de Zvw (en de Jeugdwet). Zie www.monitorlangdurigezorg.nl/.

32. Aanhangsel Handelingen II 2015/16, 3425, p. 2. Er zijn uitzonderingen op deze regel. Voor kleinschalige woonvoorzieningen (intramurale zorg) is het toegestaan om winst uit te keren. mogen winst uitkeren. ${ }^{33}$ Dit geldt uiteraard ook voor privéklinieken. ${ }^{34}$ Hierbij moet worden bedacht dat voor stichtingen op grond van Boek $2 \mathrm{BW}$ winstuitkering (aan oprichters) te allen tijde is uitgesloten. ${ }^{35}$ Pas als deze instellingen bijvoorbeeld de BV als rechtsvorm hebben, kan er winst worden uitgekeerd.

ZBC's voor medisch specialistische zorg, instellingen voor intramurale geestelijke gezondheidszorg en intramurale gehandicaptenzorg mogen geen winst uitkeren op grond van de WTZi. ${ }^{36}$ Vaak hebben deze instellingen de rechtsvorm stichting. Als deze instellingen de rechtsvorm van een BV (of een andere rechtsvorm waarbij winstuitkering is toegestaan) aannemen, moet uit de statuten voldoende blijken dat de instelling niet het doel heeft om winstuitkeringen te doen aan de aandeelhouders. ${ }^{37}$

\subsection{Wetsvoorstel Wet vergroten}

investeringsmogelijkheden in medisch-specialistische zorg

De Wet vergroten investeringsmogelijkheden in medisch-specialistische zorg zal een nieuw hoofdstuk toevoegen aan de WTZi. Artikel 5 lid 2 WTZi wordt dan geschrapt. Op grond van het toe te voegen hoofdstuk aan de WTZi mogen ZBC's na inwerkingtreding van deze wet - onder specifieke voorwaarden $^{38}$ - winst gaan uitkeren. Dat kan zich echter pas voordoen als een $\mathrm{ZBC}$ in de vorm van een stichting zich omzet in bijvoorbeeld een BV. Het verbod op winstuitkering blijft van kracht voor zorgaanbieders van intramurale geestelijke gezondheidszorg en intramurale gehandicaptenzorg. ${ }^{39}$

Volgens De Jongh en Houwen gaan de gereguleerde winstuitkering en het verbod op winstuitkering voor intramurale Wlzzorg gelden voor onderaannemers in het geval dat de uitbestedende instelling zelf geen zorg verleent. Voor de uitbestedende instelling geldt het verbod op winstuitkering dan niet. ${ }^{40}$ Zodra deze (uitbestedende) instellingen de stichtingsvorm hebben omgewisseld voor een BV-vorm, kunnen zij zonder beperkingen winst uitkeren. ${ }^{41}$ De vraag is of dat de bedoeling is.

33. Art. 3.1 jo. art. 1.2 Uitvoeringsbesluit WTZi. Het verbod op winstuitkering dat is neergelegd in de WTZi geldt niet voor zorgaanbieders die alleen zorg vanuit de Wmo leveren.

34. Privéklinieken vallen niet onder het verbod op winstuitkering omdat de WTZi niet geldt voor instellingen die niet-verzekerde zorg leveren.

35. Art. 2:285 lid 3 BW.

36. Art. 3.1 jo. art. 1.2 Uitvoeringsbesluit WTZi.

37. Het wordt dan niet als bezwaar gezien om ook BV's een toelating te verlenen. Zie Aanhangsel Handelingen II 2012/13, 2032, p. 3.

38. Art. $16 \mathrm{ct} / \mathrm{m} 16 f \mathrm{WTZi}$ (nieuw). Deze artikelen gelden ook voor ziekenhuizen.

39. Art. 16b WTZi (nieuw). Kamerstukken II 2011/12, 33168, 3, p. 6 en 34.

40. De Jongh \& Houwen 2015, p. 219. Zie ook Kamerstukken II 2016/17, 23235,167 , p. 25.

41. De Jongh \& Houwen 2015, p. 221 


\subsection{Wetsvoorstel Wtza en Aanpassingswet Wtza}

Het wetsvoorstel Wtza voorziet in een meldplicht en een vergunningsplicht voor alle nieuwe aanbieders van zorg. ${ }^{42}$ Een zorgaanbieder mag pas starten met de verlening van zorg, nadat dit is gemeld aan de minister voor Medische Zorg. Doel van de meldplicht is om het toezicht op de kwaliteit van zorg, zoals bedoeld in de Wet kwaliteit, klachten en geschillen zorg (Wkkgz), bij nieuwe zorgaanbieders effectiever vorm te geven. Naast de meldplicht wordt ook de (toelatings)vergunningsprocedure vernieuwd. ${ }^{43}$ Een vergunning kan in de toekomst worden geweigerd indien de zorgaanbieder niet voldoet aan de kwaliteitseisen uit de Wkkgz. ${ }^{44}$ De Aanpassingswet Wtza regelt de gevolgen die voortvloeien uit de Wtza. ${ }^{45}$

Privéklinieken die (nog) niet in het bezit zijn van een WTZitoelating, krijgen de mogelijkheid om binnen twee jaar een (toelatings)vergunning aan te vragen. ${ }^{46}$ Onderaannemers vallen niet onder de reikwijdte van de meldplicht (en vergunningsplicht). ${ }^{47}$ Dit volgt uit de omschrijving van het begrip 'instelling'. Aan het slot van de begripsomschrijving staat dat de instelling die een deel van de zorg binnen een andere instelling verleent, wordt uitgezonderd. Een onderaannemer wordt dus niet als een instelling - en dientengevolge ook niet als een zorgaanbieder - in de zin van dit wetsvoorstel aangemerkt. ${ }^{48}$ Dit sluit aan bij het uitgangspunt van de Wkkgz, dat onderaannemers hun activiteiten verrichten onder de verantwoordelijkheid van de hoofdaannemer. ${ }^{49}$ De hoofdaannemer is eindverantwoordelijk voor de kwaliteit van zorg.

\subsection{Tussenbeschouwing}

De vraag is of onderaannemingsconstructies in strijd zijn met de WTZi dan wel de geest van de WTZi en in hoeverre de genoemde wetsvoorstellen op het antwoord nog invloed hebben. Naar huidig recht behoeven onderaannemings-BV's geen toelating te hebben op grond van de WTZi en zoals het er nu uitziet, behoeven onderaannemings-BV's ook in de nabije toekomst geen toelatingsvergunning te hebben. In de zorgsector wordt onderaanneming geaccepteerd. ${ }^{50}$ Onderaannemingsconstructies zijn niet in strijd met de WTZi.

42. Het gaat om aanbieders van zorg als bedoeld in de Wkkgz. Op grond van de huidige WTZi wordt een groot deel van de instellingen van rechtswege (dus automatisch) toegelaten. Voordat de zorgverlening wordt aangeboden, wordt dus niet van alle instellingen die een toelating moeten hebben, getoetst of er voldoende waarborgen aanwezig zijn voor een transparante en ordelijke bestuursstructuur en bedrijfsvoering. Daarbij komt dat de toelatingseisen niet specifiek gericht zijn op de kwaliteit van de zorg.

43. Kamerstukken II $2016 / 17,34767,3$, p. 2.

44. Art. 5 Wtza (nieuw) jo. art. 3, 7 en 9 Wkkgz.

45. Bijv. de wijziging van de Wmg door de overheveling van een deel van het extern toezicht van de IGJ naar de NZa. Het toezicht van de IGJ zal zich beperken tot kwaliteit van zorg, zie hierover ook par. 5 .

46. Art. 14 lid 2 Wtza (nieuw), Kamerstukken II 2016/17, 34767, 3, p. 11.

47. Aangezien voor het begrip zorgaanbieder is aangesloten bij het begrip in de Wkkgz, vallen hierdoor aanbieders die als wederpartij van een pgbhouder beroeps- of bedrijfsmatig zorg verlenen onder de reikwijdte van de meldplicht.

48. Kamerstukken II 2016/17, 34767, 3, p. 6.

49. Kamerstukken II $2016 / 17,34767,3$, p. 7.

50. Zie ook De Jongh \& Houwen 2015, p. 215.
Op grond van de WTZi geldt een beperkt verbod op winstuitkering. Voor privéklinieken en thuiszorginstellingen is winstuitkering gewoon toegestaan. Wanneer deze klinieken of instellingen contracteren met onderaannemings-BV's, is de winstuitkering door de BV niet in strijd met de geest van de WTZi. Het verbod op winstuitkering geldt alleen voor ZBC's en instellingen voor intramurale geestelijke gezondheidszorg en intramurale gehandicaptenzorg (die zorg leveren vanuit de Zvw en de Wlz). Wanneer deze instellingen, waarvoor het verbod geldt, contracteren met onderaannemings-BV's, en deze BV's winst uitkeren, zou dat in strijd kunnen zijn met de geest van de WTZi.

Indien de Wet vergroten investeringsmogelijkheden in medisch-specialistische zorg wordt aangenomen, wordt de winstuitkering in het geval van ZBC's gereguleerd. Het verbod op winstuitkering blijft voor intramurale Wlz-zorg bestaan. Deze wet heeft ook tot gevolg dat onderaannemings-BV's onder de regels van deze wet gaan vallen. ${ }^{51}$ Winstuitkering door de onderaannemings-BV's kan dan in strijd zijn met de WTZi.

Het lijkt in strijd met de geest van de (huidige) WTZi als onderaanneming 'bewust' wordt gebruikt om wettelijke regels, zoals het verbod op winstuitkering, te omzeilen. ${ }^{52}$ Dat is waarschijnlijk het geval bij de beschreven constructie in paragraaf 2.2. De vraag is wel hoe vaak onderaanneming 'bewust' wordt ingezet bij zorginstellingen die op grond van de WTZi geen winst mogen uitkeren. ${ }^{53} \mathrm{Er}$ moet voor worden gewaakt dat 'alle' zorginstellingen over één kam worden geschoren. Uit onderzoek zal moeten blijken om hoeveel gevallen en welke bedragen het daadwerkelijk gaat. ${ }^{54}$

\section{WNT}

De WNT regelt sinds 1 januari 2013 de hoogte van de bezoldiging van bestuurders in de semipublieke sector. Doel van de WNT is normering en maximering van bezoldigingen in de semipublieke sector. ${ }^{55}$ De WNT is sindsdien door verschillende wetten aangepast. ${ }^{56}$ Sinds 1 juli 2017 geldt de Evaluatiewet WNT. ${ }^{57}$ Naar aanleiding van de wetsevaluatie van de WNT heeft het kabinet een verbeteragenda opgesteld. ${ }^{58}$ De Evalua-

51. Voorwaarde is ook dat de uitbestedende zorgaanbieder zelf geen zorg verleent.

52. Zie de opmerking van voormalig staatssecretaris Van Rijn van VWS, Kamerstukken II 2016/17, 23235, 167, p. 27.

53. Bij instellingen waarbij winstuitkering is toegestaan, zal het doel niet zijn het verbod om winstuitkering te omzeilen.

54. Zie ook C. van de Haak \& F. van der Lee, Winst maken is in de zorg nog te veel een vies woord, Skipr Daily 4 december 2017. De misstanden waarover Het Financieele Dagblad bericht, zijn volgens hen uitzondering op de regel.

55. Kamerstukken II 2010/11, 32600, 3, p. 6.

56. Bijv. Aanpassingswet WNT, Reparatiewet WNT en Wet verlaging bezoldigingsmaximum WNT.

57. Wijziging van de Wet normering bezoldiging topfunctionarissen publieke en semipublieke sector naar aanleiding van de wetsevaluatie (Evaluatiewet WNT), Stb. 2017, 239.

58. Kamerstukken II 2015/16, 34366, 1 en de bijhorende bijlage voor het rapport. 


\section{Maandblad}

Ondernemingsrecht

tiewet WNT bevat(te) de maatregelen uit deze verbeteragen$\mathrm{da}$, waarvoor een wetswijziging noodzakelijk is. ${ }^{59}$

De vraag is of onderaannemingsconstructies in strijd zijn met de WNT dan wel de geest van de WNT.

\subsection{Huidig recht}

Zorginstellingen die op grond van artikel 5 WTZi een toelating hebben, vallen op grond van Bijlage 1 onder de reikwijdte van de WNT. Voor ZBC's en instellingen op het terrein van geestelijke gezondheidszorg, gehandicaptenzorg en thuiszorg geldt dus in beginsel de WNT. Voor de bestuurders van WTZi-toegelaten instellingen geldt het bezoldigingsmaximum. ${ }^{60}$ Voor 2018 is het bezoldigingsmaximum EUR $187.000 .^{61}$

Op onderaannemings-BV's, die geen WTZi-toelating (nodig) hebben, is de WNT niet van toepassing, aangezien Bijlage 1 bij de WNT aanknoopt bij de WTZi-toelating.

\subsection{Evaluatiewet WNT}

Of onderaannemingsconstructies in strijd zijn met (de geest van) de WNT, is afhankelijk van de vraag wat tot de semipublieke sector wordt gerekend. Kunnen onderaannemings-BV's hiertoe worden gerekend? Hierover verschillen het kabinet en de Raad van State van mening. Het kabinet wilde met de Evaluatiewet WNT de criteria voor toepasselijkheid van de WNT op zorginstellingen aanpassen. Hierdoor zou de reikwijdte van de WNT worden uitgebreid tot organisaties die zelf geen WTZi-toelating hebben, maar de feitelijke werkzaamheden doen die zijn uitbesteed door WTZi-instellingen. Op advies van de Raad van State heeft het kabinet besloten hiervan af te zien. Belangrijk argument van de Raad van State was dat het enkele feit dat een onderneming een overeenkomst sluit met een semipublieke instelling deze zelf nog niet tot semipublieke instelling maakt. ${ }^{62}$

De regering wilde het wetsvoorstel niet vertragen en beraadt zich nog of, op welke termijn en in welke vorm zij nog maatregelen wil treffen. ${ }^{63}$ Minister Bruins voor Medische Zorg heeft aangekondigd, samen met de minister van Binnenlandse Zaken en Koninkrijksrelaties (BZK), te bezien op welke wijze dergelijke constructies op de meest effectieve wijze alsnog kunnen worden tegengegaan. ${ }^{64}$

\subsection{Tussenbeschouwing}

Onderaannemingsconstructies in de zorg zijn niet in strijd met de WNT. Of deze constructies in strijd zijn met de geest van de WNT is afhankelijk van wat moet worden verstaan onder de semipublieke sector. Onwenselijk is dat onderaanneming 'bewust' wordt gebruikt om wettelijke regels, zoals het beloningsmaximum voor bestuurders, te omzeilen. Dit is waarschijnlijk het geval bij de beschreven constructie in para-

59. Kamerstukken II 2016/17, 34654, 3, p. 1.

60. Art. 1.3 lid 1 onder d jo. art. 2.1 lid 1 jo. Bijlage 1 VWS onder 7 WNT.

61. Stcrt. 2017, 51696.

62. Kamerstukken II 2016/17, 34654, 4, p. 6.

63. Kamerstukken II 2016/17, 34654, 6, p. 6.

64. Kamerstukken II 2017/18, 30111, 105, p. 2. graaf 2.2. Uit onderzoek zal moeten blijken om hoeveel gevallen het daadwerkelijk gaat en in hoeverre de beloning uitstijgt boven het bezoldigingsmaximum.

\section{Toezicht}

Is er (voldoende) (toe)zicht op onderaanneming(sconstructies) in de zorgsector? Deze vraag staat centraal in deze paragraaf. Intern toezicht bij zorginstellingen vindt plaats door de raad van toezicht. Extern toezicht in de zorgsector wordt uitgeoefend door de Inspectie Gezondheidszorg en Jeugd (IGJ), ${ }^{65}$ de Nederlandse Zorgautoriteit (NZa) en het CIBG. ${ }^{66,67}$ Daarnaast blijken zorgverzekeraars en zorgkantoren in dit geval ook een rol te hebben.

\subsection{Raad van toezicht}

In aanvulling op de regels uit Boek $2 \mathrm{BW}$ worden in de WTZi ook eisen aan het bestuur van zorginstellingen gesteld. ${ }^{68}$ Sommige zorginstellingen dienen verplicht een raad van toezicht te hebben. ${ }^{69}$ Dit geldt voor ZBC's en instellingen voor geestelijke gezondheidszorg, gehandicaptenzorg en thuiszorg. ${ }^{70}$ Onderaannemings-BV's hoeven geen raad van toezicht te hebben, aangezien voor deze BV's geen WTZi-toelating nodig is.

De taak van de raad van toezicht is het houden van toezicht op het beleid van het bestuur. ${ }^{71}$ In hoeverre heeft de raad vanuit die rol zicht op onderaanneming? De WTZi geeft daarop geen antwoord, maar dit kan wel worden afgeleid uit de Governancecode Zorg, die per 1 januari 2017 geldt. $^{72}$

65. De Inspectie Jeugdzorg en de Inspectie voor de Gezondheidszorg zijn per 1 oktober 2017 gefuseerd tot één organisatie. Momenteel luidt de naam Inspectie Gezondheidszorg en Jeugd in oprichting (IGJ i.o.), omdat de Inspectie Gezondheidszorg en Jeugd wettelijk gezien nog geen formele naam is.

66. De letters stonden oorspronkelijk voor Centraal Informatiepunt Beroepen Gezondheidszorg. Momenteel wordt alleen de afkorting nog als naam gebruikt.

67. Een recent voorbeeld is het onderzoek naar goed bestuur binnen de Zorggroep Alliade te Heerenveen, Utrecht, april 2016 van IGZ en NZa (hierna: Onderzoek Alliade 2016). Zie www.rijksoverheid.nl/ documenten/rapporten/2016/07/22/onderzoek-naar-goed-bestuurbinnen-de-zorggroep-alliade-te-heerenveen.

68. Zie art. 9 lid 1 onderdeel b WTZi en art. $6.1 \mathrm{t} / \mathrm{m} 6.5$ Uitvoeringsbesluit WTZi (de zogenoemde transparantie-eisen).

69. Art. 6.1 Uitvoeringsbesluit WTZi. Zie over de gevolgen voor het intern toezicht door het wetsvoorstel Wet bestuur en toezicht rechtspersonen, A.G.H. Klaassen, Van zorginstellingen, zorgverzekeraars en patiëntenverenigingen en het wetsvoorstel Wet bestuur en toezicht rechtspersonen, O\&F 2017, p. 16 e.v., en van dezelfde auteur: Het wetsvoorstel Wet bestuur en toezicht rechtspersonen en de semipublieke sector: een betere aansluiting op Boek $2 \mathrm{BW}$ is wenselijk, Ondernemingsrecht 2017/107.

70. Art. 2.1 lid 4 onder a jo. lid 5 Uitvoeringsbesluit WTZi.

71. Art. 6.1 lid 1 onder a Uitvoeringsbesluit WTZi. Zie ook bepaling 6.1 Governancecode Zorg.

72. De Governancecode Zorg is verplicht voor zorginstellingen die lid zijn van een van de organisaties van de Brancheorganisaties Zorg (BoZ), te weten ActiZ (organisaties van zorgondernemers), GGZ Nederland, NFU (Nederlandse Federatie van Universitair Medische Centra), NVZ (Nederlandse Vereniging van Ziekenhuizen) en VGN (Vereniging Gehandicaptenzorg Nederland). De Governancecode Zorg geldt ook voor de met de zorginstelling verbonden groeps- en dochtermaatschappijen die zorg verlenen. 
Elke vorm van persoonlijke bevoordeling en belangenverstrengeling van bestuurders dient te worden voorkomen en de schijn hiervan dient te worden vermeden, zo staat in deze Governancecode Zorg. ${ }^{73}$ Wanneer een bestuurder van een zorginstelling een (onderaannemings)overeenkomst aangaat met een BV waarvan hij bestuurder en/of aandeelhouder is, is in elk geval sprake van schijn van belangenverstrengeling. ${ }^{74}$ Een bestuurder dient elke vorm en/of schijn van belangenverstrengeling te melden aan (de voorzitter van) de raad van toezicht en de raad besluit of er sprake is van belangenverstrengeling en hoe daarmee wordt omgegaan. ${ }^{75}$ Daarnaast geldt op grond van de Governancecode Zorg dat een lid van het bestuur van een zorginstelling niet tegelijk een vergelijkbare functie kan vervullen binnen hetzelfde verzorgingsgebied. ${ }^{76}$

Hoewel de Governancecode Zorg niets expliciet bepaalt over onderaanneming, kan wel worden afgevraagd of onderaanneming, zoals beschreven in paragraaf 2.2, past binnen de waarden en normen die op grond van de Governancecode Zorg gelden voor een zorginstelling. ${ }^{77}$ De raad van toezicht zou in elk geval op de hoogte moeten zijn van onderaanneming, uitgevoerd door 'privé'-BV's, en daarover een passend oordeel moeten geven. De vraag is wel of de raad van toezicht corrigerend durft op te treden. ${ }^{78}$ Letten de leden van de raad voldoende op het morele kompas? ${ }^{79}$

\subsection{IGJ, NZa en $C I B G^{80}$}

\section{IGJ}

Op grond van de WTZi houdt de IGJ, naast het toezicht op de kwaliteit van de zorg, ook toezicht op het verbod op winstuitkering (en een ordelijke en controleerbare bedrijfsvoering). ${ }^{81}$ Wanneer een instelling ondanks het voor die zorginstelling geldende verbod op winstuitkering toch winst uitkeert, kan de IGJ een last onder bestuursdwang opleggen. Ook

73. Bepaling 2.6.1 Governancecode Zorg.

74. Uit Onderzoek Alliade 2016, p. 12 blijkt dat er sprake is van schijn van belangenverstrengeling als een bestuurder overeenkomsten aangaat met zijn privéonderneming.

75. Bepaling 2.6.1 Governancecode Zorg.

76. Bepaling 2.6.2 Governancecode Zorg. In Onderzoek Alliade 2016, p. 12 wordt opgemerkt dat de Zorgbrede Governancecode (de voorganger van de Governancecode Zorg) niet is nageleefd omdat de bestuurders van Alliade ook bestuurder waren van hun privéonderneming. Er wordt alleen niet verwezen naar art. 3.3.2 Zorgbrede Governancecode, waarin hetzelfde staat als in bepaling 2.6.2 Governancecode Zorg.

77. Principe 2 van de Governancecode Zorg. Het gaat om waarden zoals integriteit, aanspreekbaarheid en betrouwbaarheid. De maatschappelijke positie van zorgorganisaties vraagt ook om sensitiviteit voor publieke waarden als rechtmatigheid, rechtvaardigheid en rechtszekerheid. De waarden en normen bepalen mede de mogelijkheden tot en invulling van de samenwerking met partijen die bijdragen aan de prestaties van de zorgorganisatie. Zie bepaling 2.1.3 Governancecode Zorg. Zie hierover ook www.actiz.nl/nieuws/web/ouderenzorg/open/2017/12/degovernancecode-zorg-en-bv-constructies.

78. Uit Kamerstukken II 2014/15, 32012, 23, p. 3 blijkt dat de raden van toezicht te vaak handelingsverlegen zijn.

79. Kamerstukken II 2016/17, 23235, 167, p. 27 en 31.

80. De Inspectie SZW en het Openbaar Ministerie doen strafrechtelijk onderzoek naar ernstige vermoedens van fraude.

81. Art. 35 WTZi. kan de minister van VWS, op advies van de IGJ, (uiteindelijk) de WTZi-toelating intrekken. ${ }^{82}$ De IGJ heeft tot nu toe één keer een last onder dwangsom opgelegd aan een instelling die het verbod op winstuitkering heeft overtreden. ${ }^{83}$ Met de Aanpassingswet Wtza wordt het toezicht van de IGJ op het verbod op winstuitkering (en de financiële bedrijfsvoering) overgeheveld naar de NZa. ${ }^{84}$

\section{$N Z a$}

De NZa houdt, naast het markttoezicht, toezicht op de zorgverzekeraars en de zorgkantoren. Het gaat dan om de rechtmatige en/of doelmatige uitvoering van de $\mathrm{Zvw}_{\mathrm{vw}}$ en de Wlz. ${ }^{85} \mathrm{De}$ $\mathrm{NZa}$ kan regels stellen met betrekking tot de controle door zorgverzekeraars en zorgkantoren. ${ }^{86}$ Het gaat erom dat de werkelijk geleverde zorg (al dan niet door onderaanneming) door een zorgaanbieder bij de zorgverzekeraar en het zorgkantoor wordt gedeclareerd. ${ }^{87} \mathrm{Ik}$ kom op de rol van de zorgverzekeraars en zorgkantoren in paragraaf 5.3 nog terug. De NZa heeft in 2016 aan de staatssecretaris van VWS gemeld dat de huidige capaciteit voor toezicht op rechtmatigheid op dit moment toereikend is. ${ }^{88}$

\section{$C I B G$}

Het CIBG houdt toezicht op de uitvoering van de WNT. ${ }^{89}$ Overtreedt een organisatie of functionaris de WNT, dan geeft het CIBG altijd voldoende mogelijkheid tot herstel. ${ }^{90}$ Het CIBG heeft tot nu toe nog geen last onder dwangsom opgelegd voor een overtreding van de WNT. ${ }^{91}$

82. $\quad$ Art. 37 en 13 lid 2 WTZi.

83. Aanhangsel Handelingen II 2015/16, 2693. Uit het Onderzoek Alliade 2016, p. 17 bleek dat het verbod op winstuitkering niet was overtreden.

84. Kamerstukken II 2016/17, 34768, 3, p. 2 en 4. De (toezichts)taken sluiten niet goed aan op de primaire toezichtstaken van de IGJ, die meer gericht zijn op de kwaliteit en veiligheid van zorg. In het wetsvoorstel Wet vergroten investeringsmogelijkheden medisch-specialistische zorg wordt het toezicht op het verbod op winstuitkering ook overgeheveld naar de NZa.

85. Art. 16 onder a, b en d Wmg.

86. Art. 27 en $31 \mathrm{Wmg}$. Zie ook art. 35 en $36 \mathrm{Wmg}$.

87. Art. $35 \mathrm{Wmg}$. Een zorgaanbieder mag alleen declareren tegen de daarvoor geldende prestaties en tarieven, en het is een ziektekostenverzekeraar verboden een ander tarief te betalen of te vergoeden.

88. Aanhangsel Handelingen II 2015/16, 3426, p. 5. De totale capaciteit van de NZa is op dit moment bijna $100 \mathrm{fte}$. Een groot deel van deze capaciteit wordt ingezet voor het toezicht op de rechtmatige uitvoering van de Zvw en de Wlz door respectievelijk zorgverzekeraars en zorgkantoren (zie Aanhangsel Handelingen II 2015/16, 3425, p. 4). De inzet van capaciteit wisselt in relatie tot de accenten die de NZa jaarlijks in het toezicht legt.

89. Art. 1 Besluit aanwijzing toezichthouders WNT Ministerie van Volksgezondheid, Welzijn en Sport.

90. CIBG, Onderzoek en handhaving WNT. Zie www. jaarverantwoordingzorg.nl/wnt/toezicht-en-handhaving.

91. Het CIBG heeft de afgelopen jaren wel in een aantal gevallen een concept-last onder dwangsom gestuurd. Een definitieve last onder dwangsom is nooit gestuurd omdat zorginstellingen het inkomen tijdig naar beneden hebben bijgesteld, zie Eikelenboom \& Ten Katen 2017a; 2017b. 


\section{Hoe komen deze (externe) toezichthouders aan bun informatie?}

Op grond van de Regeling verslaggeving WTZi geldt dat ZBC's en instellingen voor geestelijke gezondheidszorg, gehandicaptenzorg en thuiszorg ${ }^{92}$ gehouden zijn hun jaarverslaggeving op te stellen met gebruikmaking van het model Jaarverantwoording, dat staat op de website www. jaarverantwoordingzorg.nl. ${ }^{93}$ De jaarstukken dienen een controleverklaring ${ }^{94}$ van een (onafhankelijke) accountant te bevatten. Sinds $2010^{95}$ dient de zorginstelling volgens het model Jaarverantwoording gegevens op te nemen over onderaanneming/uitbesteding, zoals hoeveel kosten ermee zijn gemoeid en aan welke zorgaanbieders zorg is uitbesteed. ${ }^{96}$

Voor sommige zorginstellingen gelden minder zware eisen met betrekking tot de jaarverantwoording. ${ }^{97}$ Voor zorginstellingen met een omzet van minder dan EUR 12 miljoen is een beoordelingsverklaring van de accountant ${ }^{98}$ voldoende. Daarnaast gold dat instellingen die WTZi-toegelaten zijn en die alleen zorg in onderaanneming hebben verleend, zich tot en met het verslagjaar 2016 beperkt hoefden te verantwoorden om onnodige administratieve lasten te voorkomen. ${ }^{99}$ Vanaf het verslagjaar 2017 is deze beperkte verantwoording ${ }^{100}$ niet meer toegestaan. ${ }^{101}$ Voor instellingen met een omzet minder dan EUR 700.000 geldt (nog steeds) een vereenvoudigde verantwoording (de zogenoemde micro-entiteiten). Tot het verslagjaar $2017^{102}$ gold de eis van een samenstellingsverklaring. 103

Indien zorginstellingen een volledige jaarrekening moeten indienen en dat om wat voor reden dan ook niet doen, treedt de IGJ handhavend op. Zo moe(s)ten voor het boekjaar 2014

92. Art. 1 onder a Regeling verslaggeving WTZi jo. art. 1.2 Uitvoeringsbesluit WTZi.

93. Art. 8a lid 1 Regeling verslaggeving WTZi. Voor 1 januari 2018: www. jaarverslagenzorg.nl.

94. Met een controleverklaring geeft de accountant een oordeel over de jaarrekening met een redelijke mate van zekerheid, zie www.nba.nl/tools-envoorbeelden/uitleg-gebruik-accountantverklaringen/.

95. Aanhangsel Handelingen II 2009/10, 882.

96. Zie Jaarverantwoording 2017, A.1.9: KvK-nummer van onderaannemer en hoe de zorginstelling toeziet op de kwaliteit van de uitbestede zorg. Doel van deze gegevens is om na te gaan hoe een correctie op dubbeltellingen kan worden aangebracht. Deze gegevens zijn niet openbaar. Jaarverantwoording 2017, p. 10 en A.1.9 en p. 98.

97. Art. 3 onder $\mathrm{f}$ en $\mathrm{g}$ Regeling verslaggeving WTZi.

98. Met een beoordelingsverklaring geeft de accountant een conclusie met een beperkte mate van zekerheid. Zie www.nba.nl/tools-en-voorbeelden/ uitleg-gebruik-accountantverklaringen/.

99. Aanhangsel Handelingen II 2015/16, 3425, p. 3.

100. De gegevens uit de beperkte verantwoording bevatten niet voldoende informatie voor toezicht en handhaving door de IGJ voor het waarborgen van de kwaliteit van zorg. Zie www.jaarverantwoordingzorg.nl/ actueel/nieuws/2017/11/november/vervallen-beperkte-verantwoording. Dit geldt ook voor zorg gefinancierd uit het $\mathrm{pgb}$.

101. Instellingen die geen WTZi-toelating nodig hebben, wordt aangeraden hun toelating in te trekken.

102. Stcrt. 2015,44555 .

103. Met een samenstellingsverklaring ondersteunt de accountant de organisatie bij het opstellen van de jaarrekening. Zie www.nba.nl/tools-envoorbeelden/uitleg-gebruik-accountantverklaringen/. Deze instellingen hoeven straks niet meer een samenstellingsverklaring te publiceren, aangezien de kosten niet proportioneel worden geacht. Stcrt. 2017, 68816. nog 57 instellingen hun jaarrekening indienen. ${ }^{104}$ Doen zij dat niet, dan riskeren zij een last onder dwangsom. ${ }^{105}$

Voor onderaannemings-BV's gelden de eisen van Boek 2 BW over de jaarverslaggeving. Zij vallen zonder WTZi-toelating niet onder de Regeling verslaggeving WTZi. Uitgangspunt is dat de BV haar jaarrekening openbaar makkt volgens titel 9 van Boek 2 BW. Voor kleine BV's geeft de wet een vrijstelling van deze verplichting. Bij een omzet van minder dan EUR 12 miljoen hoeft alleen een vereenvoudigde balans openbaar te worden gemaakt en is geen accountantscontrole vereist. ${ }^{106} \mathrm{Dit}$ geldt ook voor micro-entiteiten. ${ }^{107}$

In het model Jaarverantwoording dienden ZBC's en instellingen voor geestelijke gezondheidszorg, gehandicaptenzorg en thuiszorg ook de WNT-gegevens op te nemen. ${ }^{108}$ Met de Evaluatiewet WNT dienen deze gegevens alleen nog in de jaarrekening te worden opgenomen. ${ }^{109}$

Voor onderaannemings-BV geldt in beginsel artikel 2:383 BW. Op grond hiervan dienen gegevens over het bedrag aan bezoldiging van de gezamenlijke (en gewezen) bestuurders openbaar te worden gemaakt. Een opgave die herleid kan worden tot een enkele natuurlijke persoon mag achterwege blijven.

\subsection{Zorgverzekeraars en zorgkantoren}

Zorgverzekeraars en zorgkantoren zijn verantwoordelijk voor respectievelijk de uitvoering van de Zvw en de Wlz. ${ }^{110}$ In dit kader is de NZa bevoegd tot het stellen van regels op het gebied van de administratieve organisatie en interne controle van Wlz-zorgaanbieders. ${ }^{11}$ In de regeling staat:

'De zorgaanbieder legt vast of, en zo ja, in welke mate er sprake is van onderaanneming c.q. uitbesteding ${ }^{112}$ van Wlz-zorg.' ${ }^{\text {'13 }}$

104. Aanhangsel Handelingen II 2015/16, 3425, p. 3.

105. Art. 37 WTZi.

106. Art. 2:396 lid 7 BW.

107. Art. 2:395a BW.

108. Zie Jaarverantwoording 2016, Zorginstellingen en Jeugd onder C.6.

109. Art. 4.1 WNT. Zie ook Stcrt. 2017, 68816. Deze regeling is per 1 januari 2018 in werking getreden en geldt vanaf het verslagjaar 2017.

110. Zorgverzekeraars en zorgkantoren screenen een zorgaanbieder alvorens zij een contract aangaan met de zorgaanbieder; hiervoor is het portaal Raadpleging Integriteit Zorgaanbieders (RIZ) ontwikkeld. Zorgverzekeraars en zorgkantoren kunnen volgens voormalig staatssecretaris Van Rijn van VWS kritisch kijken naar de contracten die ze aangaan, zodat er niet meer wordt betaald dan nodig is, Aanhangsel Handelingen II 2015/16, 3425, p. 2 en Kamerstukken II 2015/16, 32012, 40, p. 1.

111. Art. 36 lid 3, 61 en $68 \mathrm{Wmg}$.

112. Volgens de $\mathrm{NZa}$ is er geen beleid van zorgkantoren om te sturen op onderaanneming. Dat wil daarmee niet zeggen dat er in individuele gevallen geen goede redenen kunnen zijn om zorg uit te besteden bij onderaannemers. Zie Kamerstukken II 2016/17, 34104, 168, p. 11.

113. Zie voor de laatste versie Stcrt. 2017, 27983. Deze gaat gelden per 1 januari 2018. 
De zorgaanbieder verstrekt deze informatie aan het zorgkantoor/de Wlz-uitvoerder. ${ }^{114}$ Deze eis van transparantie geldt sinds $2010 .{ }^{115}$

Ten behoeve van Wlz-zorg stelt Zorgverzekeraars Nederland ${ }^{116}$ een landelijk inkoopkader op. ${ }^{117}$ In de Nota van inlichtingen 2018 staat dat de onderaannemer in het bezit moet zijn van een WTZi-toelating. ${ }^{118}$ Onderdeel van dit inkoopkader is Bijlage $2 \mathrm{~A}$, de zogenoemde bestuursverklaring, waarmee de bestuurder van een zorgaanbieder moet verklaren dat de zorgaanbieder voldoet aan de eisen met betrekking tot onderaanneming. Het gaat hierbij om de kwaliteit van zorg. ${ }^{119}$

\subsection{Tussenbeschouwing}

Er gelden verschillende regelingen waardoor zorgaanbieders transparant moeten zijn over onderaanneming. In die zin is er voldoende zicht op onderaanneming. Afgevraagd kan worden of deze transparantie alleen wordt gebruikt om de kwaliteit van zorg in de gaten te houden of ook om uitwassen in kaart te krijgen. Is het toezicht actief genoeg als het gaat om 'ongewenste vormen van' onderaanneming? Vindt er voldoende analyse van jaardocumenten door de externe toezichthouders plaats? ${ }^{120}$ Het valt toe te juichen dat in de Aanpassingswet Wtza het toezicht op het verbod tot winstuitkering wordt overgeheveld van de IGJ naar de NZa. De NZa is meer capabel om te kijken naar de financiële kant van het verhaal dan de IGJ. Het is dus afwachten wat de NZa gaat doen, na inwerkingtreding van de Wtza en de Aanpassingswet Wtza. ${ }^{121}$

Het lijkt erop dat het wetgevend (handhavings)instrumentarium toereikend is. Opvallend is wel dat er weinig sancties worden opgelegd. Het is lastig gissen naar een toereikende verklaring. Het kan namelijk betekenen dat zorginstellingen zich keurig aan de wet houden, maar ook dat er onvoldoende toezicht is om uitwassen te signaleren. ${ }^{122}$

114. Aanhangsel Handelingen II 2009/10, 882. Deze informatie dient het zorgkantoor te gebruiken om te toetsen of de kwaliteit van de afgesproken zorgverlening gewaarborgd blijft en of de middelen van de Wlz niet oneigenlijk of ondoelmatig worden aangewend. Verder gebruikt het zorgkantoor deze informatie bij het zorginkoopproces.

115. Stcrt. 2010, 17719.

116. Zorgverzekeraars Nederland $(\mathrm{ZN})$ is een vereniging waar zorgverzekeraars lid van zijn en behartigt de belangen van alle zorgverzekeraars.

117. Zie www.zn.nl.

118. Dit geldt niet als een onderaannemer uitsluitend schoonmaakwerkzaamheden verricht of een zzp'er is. In het kader van kwaliteit van zorg wil het zorgkantoor er zicht op houden in welke omvang en met wie afspraken worden gemaakt voor onderaannemerschap.

119. Zie bijlage 2 bij Bijlage $2 \mathrm{~A}$, waarover de zorgaanbieder dient te verklaren. In de toelichting staat dat het zorgkantoor de richtlijn hanteert dat zorgaanbieders ten minste twee derde van de verwachte gecontracteerde zorg zelf leveren. Zorgkantoren willen inzicht in de totale zorgverlening, inclusief de zorgverlening door onderaannemers.

120. Kamerstukken II 2016/17, 23235, 167, p. 41.

121. Met de Aanpassingswet Wtza dient meer informatie aan de NZa te worden verstrekt dan nu onder de WTZi. Zie art. 40a Wmg (nieuw). Art. 40a Wmg (nieuw) gaat o.a. de eisen van art. 6.3, 6.4 en 6.5 Uitvoeringsbesluit WTZi bevatten.

122. Er vindt nog nader onderzoek plaats naar Alliade. Aanhangsel Handelingen II 2017/18, 409.

\section{Aanpassingen?}

\subsection{Onderaannemers als WTZi-instelling}

Het ligt voor de hand om onderaannemers die zorg verlenen ook onder de WTZi en de Aanpassingswet Wtza te laten vallen. ${ }^{123}$ Het verbod op winstuitkering op grond van de WTZi en het bezoldigingsmaximum van de WNT kunnen dan niet meer worden omzeild door onderaanneming. De gedachte uit de Wkkgz dat alleen borging van kwaliteit van zorg bij onderaanneming centraal staat, moet dan worden losgelaten (zie par. 3.3).

Het ligt voor de hand dit onderwerp mee te nemen in het wetsvoorstel Wtza en de Aanpassingswet Wtza door het wijzigen van het begrip 'instelling', zodat ook een onderaannemings-BV die zorg verleent hieronder valt. ${ }^{124}$ Als het aantal WTZi-instellingen wordt uitgebreid, wordt het toepassingsbereik $^{125}$ van de Regeling verslaggeving WTZi ${ }^{126}$ en de WNT ook meteen verruimd. Voor de zorg lijkt een aanpassing van een zorgwet ook meer voor de hand te liggen dan aanpassing van Boek 2 BW of de WNT.

Deze aanpassing moet overigens niet worden gezien als het ei van Columbus. Winstuitkering in de zorg wordt hiermee niet uitgebannen, ${ }^{127}$ aangezien het verbod op winstuitkering geldt voor een beperkt aantal instellingen. De vraag is of een winstverbod (juridisch) sluitend te krijgen is. Aan aanverwante activiteiten, zoals schoonmaakbedrijven, kan geen verbod op winstuitkering worden opgelegd. Door hoge tarieven te betalen kan toch geld aan de zorg worden onttrokken. Een andere vraag is of winstuitkering onwenselijk is. ${ }^{128}$

\subsection{Governancecode Zorg}

Kan de Governancecode Zorg worden aangescherpt, zodat onderaanneming beter in beeld komt? In de Governancecode

123. Minister Bruins voor Medische Zorg staat welwillend tegenover het idee om ook onderaannemers onder de meld- en vergunningsplicht van de Wtza te laten vallen, zie Kamerstukken II 2017/18, 34767, 6, p. 22. Dit moet dan goed worden afgestemd met het nieuwe begrip 'instelling' in de WTZi, zie art. 1 lid 1 onder f WTZi (nieuw). Art. 5 WTZi (nieuw) over het verbod op winstuitkering en Bijlage 1 VWS onder 7 (nieuw) bij de WNT gaan uit van dit nieuwe begrip 'instelling. Zie art. I onder c en IX in Kamerstukken II 2016/17, 34768, 2.

124. Minister Bruins voor Medische Zorg wil dit bezien in samenhang met de Wkkgz en meenemen bij de evaluatie van de Wkkgz, zie Kamerstukken II $2017 / 18,34767,6$, p. 22

125. Volgens J. Suijs dienen alle bedrijven die zich met zorgverlening bezighouden, te worden verplicht een jaarrekening te publiceren. Zie hierover M. ten Katen \& S. Eikelenboom, Hoogleraar accountancy: 'Zorg moet financieel veel transparanter', Het Financieele Dagblad 27 december 2017.

126. Wellicht dient ook te worden onderzocht of voor alle zorginstellingen een verplichting tot openbaarmaking van de (volledige) jaarrekening (en een controleverklaring van de accountant) wenselijk is (zie par. 5.2). Zie hierover Tweede Kamerlid Ellemeet in: G. Herderscheê, GroenLinks wil totaalverbod op winstmaken in de zorg: 'Ook voor onderaannemers', de Volkskrant 3 november 2017.

127. Dit lijkt een grote wens van een aantal Tweede Kamerleden.

128. Zie voor de mogelijkheid van winstuitkering voor Wlz-verblijf $\mathrm{H}$. Linders \& M. Weusten, Geen woorden, maar daden - waarom winstuitkering in de zorg (juist nu) belangrijk is, O\&F 2017, p. 67-68. 


\section{Maandblad \\ Ondernemingsrecht}

Zorg kan bijvoorbeeld worden opgenomen dat bestuurders verplicht zijn hun aandelenbezit in andere vennootschappen te melden. Door deze transparantie kan beter worden beoordeeld of sprake is van persoonlijke bevoordeling en/of belangenverstrengeling.

Daarnaast kan worden opgemerkt dat de Governancecode Zorg uitgaat van bepaalde waarden en normen, waarvan wellicht niet voor iedere bestuurder of lid van de raad van toezicht duidelijk is hoe deze naar de praktijk vertaald moeten worden. Wenselijk is dat binnen de NVZD en de NVTZ ${ }^{129}$ en/of andere gremia hierover een debat wordt gevoerd. ${ }^{130}$ Wellicht kan de Governance innovatie- en adviescommissie ${ }^{131}$ een uitspraak doen over de (wenselijkheid van de) beschreven constructie in paragraaf 2.2, of het debat daarover aanwakkeren. Een andere mogelijkheid is dat leden van de brancheorganisaties in de zorg vaker de gang maken naar de Governancecommissie Gezondheidszorg als de Governancecode Zorg niet juist wordt toegepast. ${ }^{132}$

\section{Conclusie en aanbevelingen}

Onderaanneming is een geaccepteerd verschijnsel en onderaannemingsconstructies zijn niet in strijd met de WTZi en de WNT. Over de vraag of onderaannemingsconstructies in strijd zijn met de geest van deze wetten kan verschillend worden gedacht. Duidelijk is dat de beschreven constructie in paragraaf 2.2 onder bepaalde voorwaarden als ongewenst kan worden gezien. Het lijkt dat er voldoende transparantie is over onderaanneming en dat het handhavingsinstrumentarium toereikend is. De vraag is wel of het toezicht actief genoeg is als het gaat om 'ongewenste vormen van' onderaanneming.

Mijn eerste aanbeveling is om gericht in kaart te brengen hoe vaak dergelijke constructies voorkomen. Duidelijk wordt dan ook meteen of het extern toezicht voldoende mogelijkheden heeft tot toezicht houden. Mijn tweede aanbeveling is dat nagedacht kan worden over aanpassing van het wetsvoorstel Wtza (en de Aanpassingswet Wtza), zodat de relevante wetgeving ook op onderaannemers van toepassing wordt, en aanpassing van de Governancecode Zorg.

Schijn bedriegt en de werkelijkheid is weerbarstig. In de berichten in de media wordt in elk geval de schijn gewekt dat er wat aan de hand is. De politiek moet afgaan op de werkelijk-

129. De NVZD is de beroepsvereniging voor bestuurders in de zorg. De NVTZ is de Nederlandse Vereniging van Toezichthouders in Zorg en Welzijn.

130. Ook voormalig minister Schippers van VWS wil(de) een debat over goed bestuur stimuleren, zie Kamerstukken II 2014/15, 32012, 23, p. 9.

131. De Governance innovatie- en adviescommissie is beschikbaar voor advies over governancevraagstukken die verder reiken dan het niveau van individuele casuïstiek en vragen om een overstijgende visie. Deze commissie zal zich niet richten op geschilbeslechting, daarvoor is de Governancecommissie Gezondheidszorg, maar zal op verzoek van de brancheorganisaties wel kunnen adviseren over governancevraagstukken die zich in de praktijk voordoen.

132. Zie ook www.actiz.nl/nieuws/web/ouderenzorg/open/2017/12/degovernancecode-zorg-en-bv-constructies. heid. Dat vergt gedegen nader onderzoek. In het begin van 2018 wil minister Bruins voor Medische Zorg al met een reactie komen. ${ }^{133}$ De vraag is of dat niet te vroeg is. 